\title{
A large Cervidae Holocene accumulation in Eastern Brazil: an example of extreme taphonomical control in a cave environment
}

\author{
Alex Hubbe ${ }^{1,2}$ and Augusto S. Auler ${ }^{*}$
}

\begin{abstract}
:
Hubbe A. and Auler A.S. 2012. A large Cervidae Holocene accumulation in Eastern Brazil: an example of extreme taphonomical control in a cave environment. International Journal of Speleology, 41(2), 297-305. Tampa, FL (USA). ISSN $0392-6672$. http://dx.doi.org/10.5038/1827-806X.41.2.15

A remarkable cervid bone accumulation occurs at a single passage (named Cervid Passage; CP) at Lapa Nova, a maze cave in eastern Brazil. CP lies away from cave entrances, is a typical pitfall passage and contains bone remains of at least 121 cervids, besides few bats, peccaries and rodents remains. There is no evidence of water (or sediment) flow at the site and in general bones lack post depositional alterations and display anatomical proximity, suggesting that the majority of the remains found inside $\mathrm{CP}$ (mainly cervids) are due to animals that after entering the cave got trapped in the site. Observations suggest that two entrances could have provided access to cervids (and the few other animals, besides bats), either by falling inside the cave or by entering by their own free will. Once inside the cave, the maze pattern would make route finding difficult, and of all passage intersections, only the one leading to CP would result in a non-return situation, starving the animal to death. Radiocarbon dates suggest that animal entrapment occurred during at least 5 thousand years, during the Holocene. The reasons why mainly cervids were found are unknown but they are probably related to the biology of this group coupled with the fact that caves provide several specific taphonomic processes that may account for a strong bias in bone accumulation. Indeed, the frequent occurrence of Cervidae in both the fossil and sub-fossil record in Brazilian caves may be related to an overall high faunal abundance or may suggest that these animals were especially prone to enter caves, perhaps in search of nutrients (as cave saltpetre) or water.
\end{abstract}

Keywords: Cervid; Lapa Nova; cave environment; taphonomy; Holocene Received 12 March 2012; Revised 10 April 2012; Accepted 31 May 2012

\section{INTRODUCTION}

The cave environment presents a number of characteristics that favours the preservation of fossil vertebrate remains, among them slower decay of carcasses and minimal bone weathering when compared to material left on the surface (Simms, 1994). As such, significant cave fossil and subfossil deposits have been recognised in many karst areas (Muldoon et al., 2009; De Waele et al., 2009; van den Bergh et al., 2009; Jass \& George, 2010; Macken et al., 2011). Furthermore, caves have contributed to valuable datable material that has helped providing critical past environmental information (Ward et al., 2003).

However, several studies have demonstrated that cave stratigraphy tends to be very complex (Campy \& Chaline, 1993; Brain, 1995; Piló et al., 2005; Auler

\footnotetext{
${ }^{1}$ Laboratório de Estudos Evolutivos Humanos, Departamento de Genética e Biologia Evolutiva, Instituto de Biociências, Universidade de São Paulo, Rua do Matão 277, São Paulo, SP - 05508-090, Brazil
}

${ }^{2}$ Instituto do Carste. Rua Barcelona, 240/302, Belo Horizonte, MG, 30360-260, Brazil (aauler@gmail.com) et al., 2006; Hubbe et al., 2011) and a considerable range of taphonomic processes may be present, requiring caution when attempting paleobiological and palaeoenvironmental reconstructions. A precise knowledge of the taphonomy of a fossil deposit is an integral and essential part of any study dealing with past environmental inferences (Behrensmeyer et al., 2000).

One taphonomical aspect of particular interest is the process of bone accumulation. Even more striking are the cases in which fossiliferous deposits have a strong bias towards single species (see White et al., 1984). This is especially true in cave environments, where some emplacement processes and species behaviour tend to favour the concentration of specific taxonomic groups. The best known example concerns animals that spend part of their lives in caves such as bats or use caves as hibernacula (e.g. the common occurrence of Ursus spelaeus in Pleistocene European cave deposits (Kurtén, 1995).

In this studywe present the description, chronological assessment and taphonomic interpretation of a remarkable accumulation of Cervidae (deer) remains at a single site in Lapa Nova (New Cave), a dolomite maze cave in southeastern Brazil. The interpretation of 


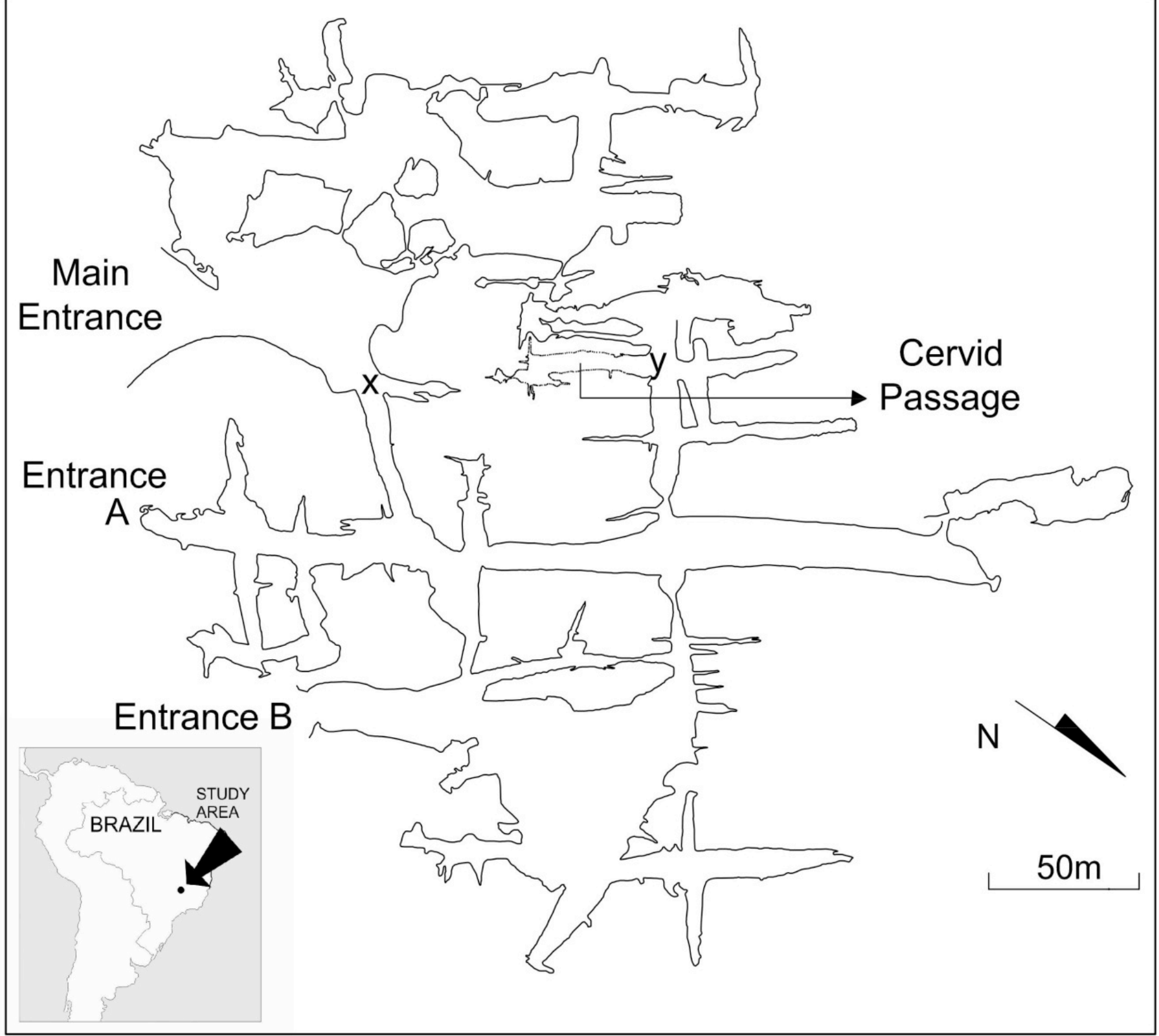

Fig. 1. Location of Lapa Nova and plan map of the cave. "X" and "Y" denote steep passages that would not allow for a return of a cervid. Survey by caving club Sociedade Excursionista e Espeleológica (SEE).

this site helps to reinforce the peculiar species-specific taphonomical processes that take place inside caves, providing an opportunity for assessing the controlling mechanisms that played a role in bone accumulation.

\section{STUDY AREA AND CAVE ENVIRONMENT}

Lapa Nova is located at the base of a dolomite residual hill very close to the urban area of Vazante, a medium size mining town in northwest state of Minas Gerais, southeastern Brazil (Fig. 1). The main cave entrance has been known since the end of the $19^{\text {th }}$ century and currently there is a yearly religious pilgrimage to the cave that brings over 3,000 visitors during a single week in early May. Although a local tourist attraction, and partly modified with tourist trails, the cave receives sparse visitation during the rest of the year. Climate in the area is seasonal, with wet austral summers and dry winters. Average precipitation is around 1,300 $\mathrm{mm} \mathrm{yr}^{-1}$. Vegetation has been largely altered due to urbanisation and cattle ranching, with original savannah and dry forest being restricted to hilly and rocky non farmed areas.

Lapa Nova is a maze cave with about $4.5 \mathrm{~km}$ of passages. The cave contains classic features of hypogene speleogenesis (Bittencourt et al., 2009) and is interpreted as being associated with acidic and possibly thermal water rising through faults. The same fault has generated very extensive zinc deposits currently being mined in the vicinity of the cave. Cave morphology comprises large passages that connect at approximately right angles (Fig. 1). There are three entrances, two providing direct access through breakdown sloping passages and the third being a vertical shaft that cannot be entered without climbing equipment. The main entrance gives access to two major areas that do not connect in the inner portion 


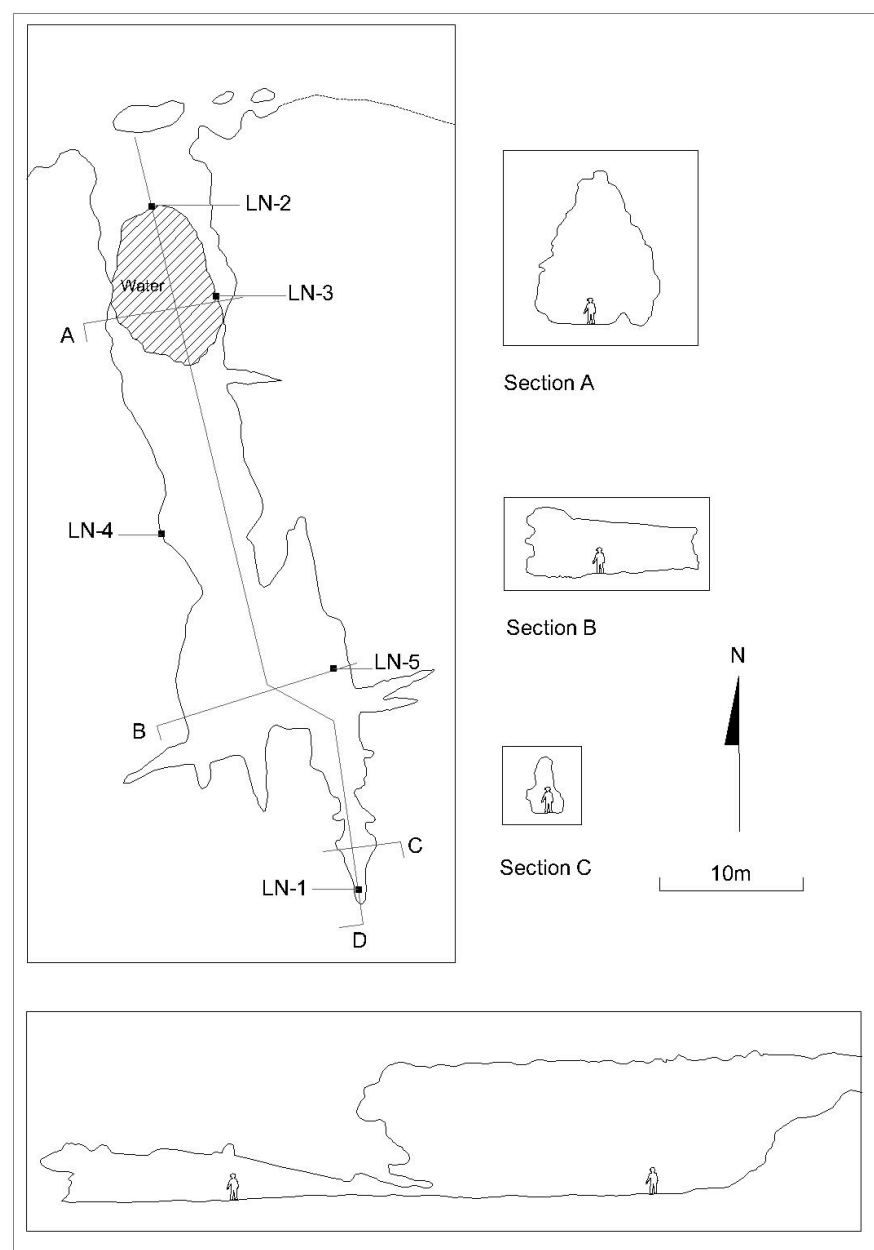

Profile D

Fig. 2. Plan map, sections and profile of the Cervid Passage (CP) with sample (LN) locations. of the cave. Both areas contain large chambers mostly filled with fine grained sediment and occasionally capped by calcite flowstone. The cave is essentially horizontal although there are few inclined passages and short climbs. An upper level develops parallel to the lower passages and can only be accessed through climbs in two separated areas of the cave.

As part of studies related to the management plan of Lapa Nova a detailed paleontological search was carried out throughout the cave. In general, the cave is non-fossiliferous with the exception of very few bats and cow remains and a single passage in the northern portion of the cave that contains a remarkable concentration of bones, mostly related to Cervidae. The Cervid Passage (CP) is about $60 \mathrm{~m}$ long with two larger sectors divided by a low ceiling (Fig. 2 and Fig. 3). Walls are quite irregular and there are few joint-controlled narrow side passages. There are no further connections to other areas of the cave and this passage can only be accessed through an abrupt $1.5 \mathrm{~m}$ deep nearly vertical section floored with smooth calcite flowstone (Fig. 4). CP floor is essentially flat and covered by subaqueous calcite. Current water levels do not exceed $0.2 \mathrm{~m}$ above the ground but a calcite water mark in the wall shows that the water may have been at least $1.9 \mathrm{~m}$ deep (above the bone accumulation) in the past.

\section{METHODS}

In order to gather accurate data on the fossiliferous deposit, a detailed survey of $\mathrm{CP}$ was performed using Suunto KB-14 compass and Suunto PM-5 clinometer, together with a Leica Disto A3 laser tape. The passage was then divided in 117 quadrangles of approximately $1 \mathrm{~m}^{2}$, allowing better control on bone

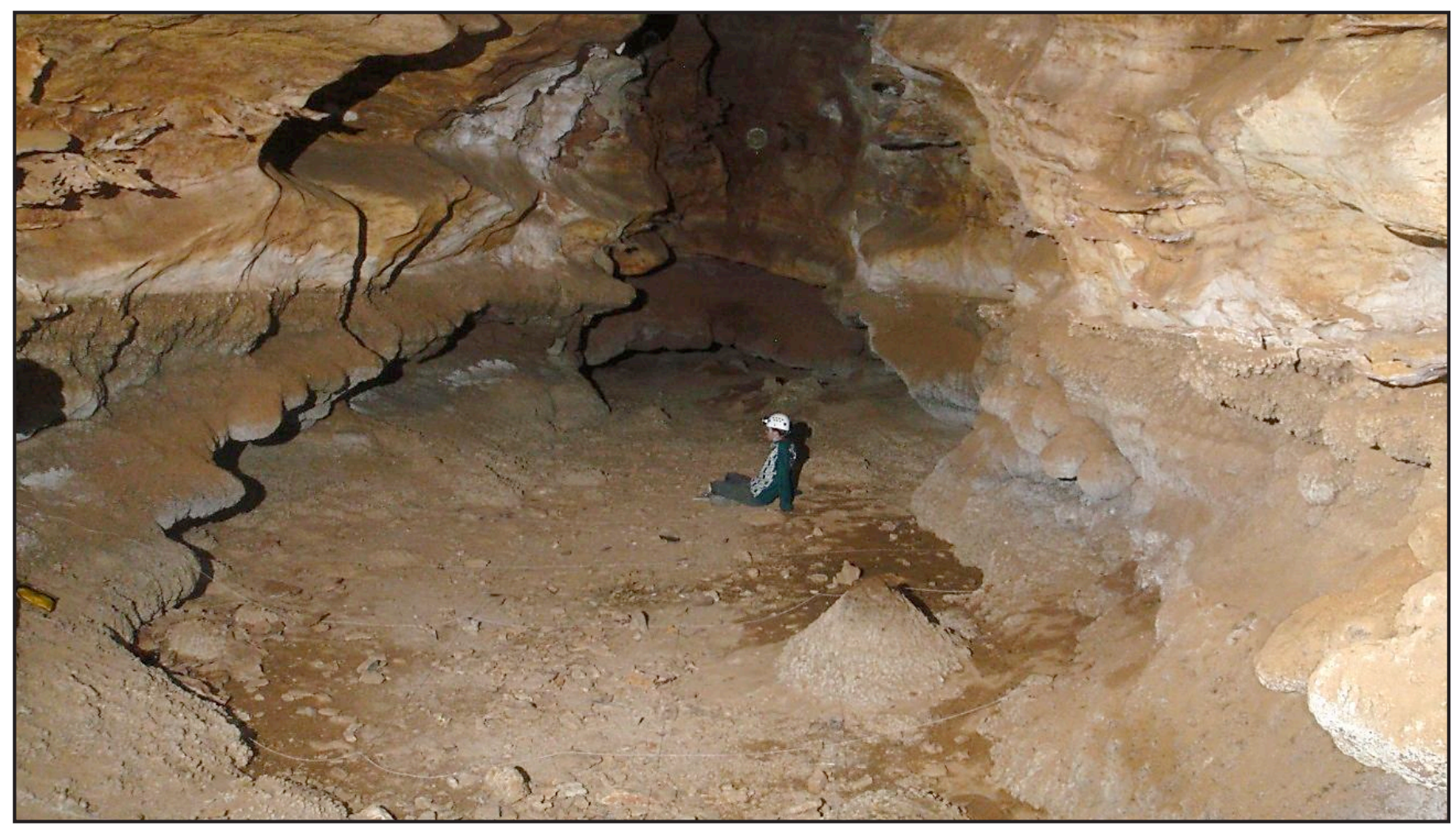

Fig. 3. View of the initial section of Cervid Passage. Horizontal past water level mark is visible below the whitish area on both walls. 


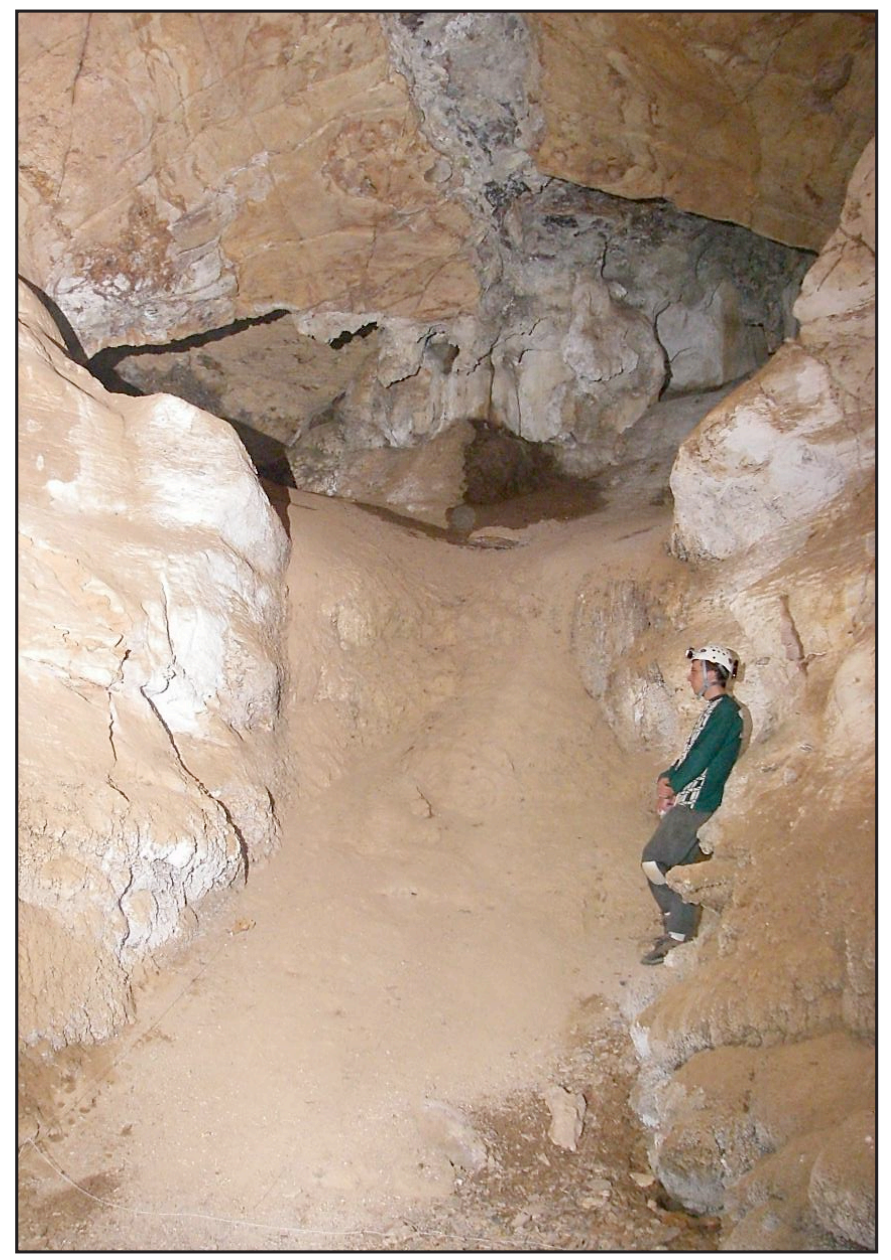

Fig. 4. Steep entrance sector of Cervid Passage. The slippery flowstone floor and the abrupt nearly vertical section near the top prevent cervid climbing back.

counting and examination. All bones available were examined in relation to post depositional alterations (fragmentation, abrasion, weathering, animal marks, polish, coating, texture, relative abundance of elements and degree of anatomical proximity/ articulation) and also for carnivore marks that would suggest a carnivore lair. During this process, bones from each taxon were analyzed and counted to estimate their minimum number of individuals (MNI). Regarding the Cervidae (by far the most abundant family represented), a preliminary search of the site showed that astragalus was quite common and well preserved, presumably because its morphology makes it less susceptible to fragmentation and its density favours the preservation as well (Lam et al., 1999). Thus, every quadrant was visually searched for this bone element and each piece found was classified by side and identified taxonomically. The total amount of left and right astragalus was quantified and the largest number of the two was used to calculate the MNI for the taxonomic groups found. No material was removed from $\mathrm{CP}$ besides five samples for radiocarbon dating.

Chronology of bone emplacement was obtained through AMS radiocarbon analyses performed at the Center for Applied Isotope Studies at the University of Georgia. Dates were calibrated with Calib Rev 6.1.0 (Stuiver \& Reimer, 1993) using the database SHCal04.

\section{RESULTS AND DISCUSSION} Animal diversity and MNI

The number of left astragalus allowed the determination of a minimum number of 121 Cervidae individuals. The vast majority belongs to Mazama (unfortunately due to morphological similarities it was not possible to identify the specimens to the species level, but they are most probably either $M$. americana or M. guazoubira). However few specimens ( 6) from a possible larger non-identified cervid species were also present. Individuals encompass different ontogenetic stages, from very young to adult, including some that show advanced stage of molar wear. Both male and female specimens were recognized. Few other mammalian taxa were found. One infant Tayassuidae (wild pig) was identified based on one jaw fragment with an erupting molar, one phalanx and few teeth. Skulls from six Desmodus rotundus (common vampire bat) were found. There was also one incisive tooth from Rodentia (rodents) and one atlas that probably belongs to this order too.

In addition to the huge bias towards Cervidae accumulation, another striking characteristic of this deposit is the intense degree of bone fragmentation. Fragments and fragmented bones were extremely abundant and scattered all over CP (Fig. 5). Besides fragmentation, the material suitable for analyses (not extremely fractured) displays no severe additional post depositional alteration. Due to the visitation history of Lapa Nova, human trampling in $\mathrm{CP}$ is interpreted as the main source of fragmentation, because bones in low and narrow areas - difficult to be reached by humans - are in excellent state of preservation. Dispersion of the material is not significant, since bones in areas of more difficult access (thus less prone to human disturbance) show close anatomical proximity. Elements of different anatomical parts can be found throughout the passage, without noticeable concentration of specific bones. An exception is provided by jaws and skulls, which are nearly absent (even as fragments), suggesting that they were most probably taken by visitors, reinforcing the

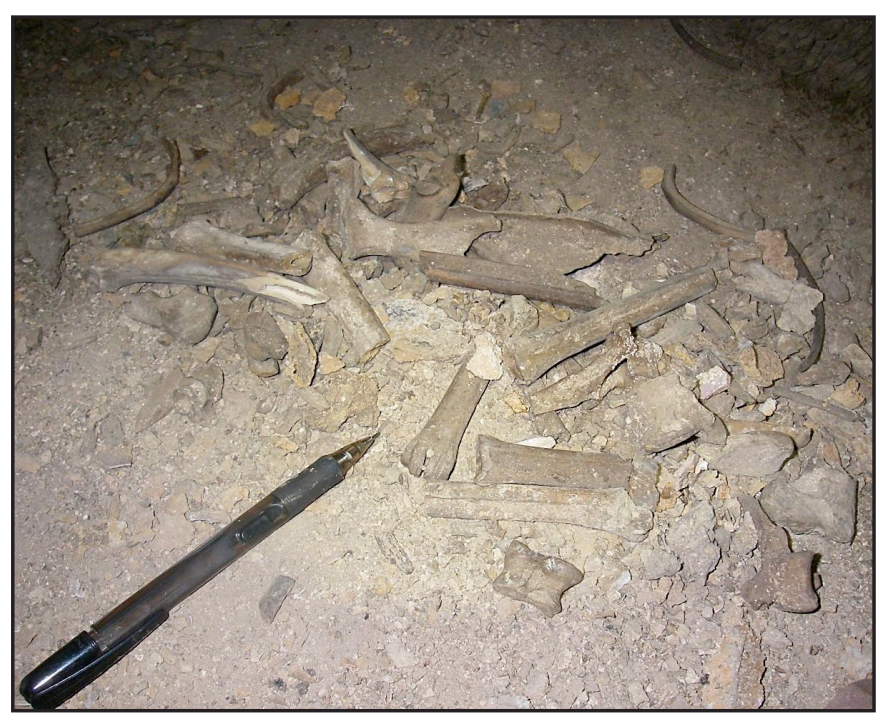

Fig. 5. A typical occurrence of fragmented cervid bones at Cervid Passage. 
interpretation that humans were the main agent of fragmentation. With the exception of one Cervidae metacarpus that presents rodent gnawing marks, bones do not show evidence of usage by carnivores, rodents or insects.

Furthermore, there is an apparent trend to increase bone concentration away from CP entrance. This subtle gradient may be due to access facilities in the area close to the entrance, favouring bone fragmentation and thus removal of heavily fragmented bones from the statistical count. At present there is a shallow (less than $0.2 \mathrm{~m}$ deep) water pond in the initial portion of $\mathrm{CP}$ during the wet season. This pond also displays a clear concentration of bones (mainly fragments), especially at its central and deepest point. This is to be expected due to floating and gravitational effect that tends to concentrate lighter bones in the center of the pond. Elsewhere in the cave, but close to $\mathrm{CP}$, there is a skull and other bones of Mazama partially covered by speleothem deposition. In the remaining areas of the cave only few bats and cow remains were found. Although no excavation, test pits or auger cores were performed, in areas where sediment columns were available (natural erosion, holes left by miners searching for saltpetre) no fossils were found.

\section{Bone emplacement}

Lund (1845), Paula Couto (1971) and Simms (1994) proposed five possible mechanisms of bone emplacement in caves: (i) by predators who used the caves as dens; (ii) by the fall of animals into vertical fissures or shafts; (iii) by death of animals that got lost after entering caves in search of water (or nutrients) or temporary shelter; (iv) by death of animals that lived in the caves; (v) by water (or sediment) transport during runoff into the caves. Condition of bone material (anthropic fragmentation, absence of other post depositional alterations and carnivore marks) allied with the vertical shaft nature of CP's entrance favours process (ii) as the ultimate process responsible for the accumulation of the faunal remains. Furthermore, based on the following reasons it is possible to exclude processes (i), (iii), (iv) and (v) as responsible for bone accumulation in this site. CP lies away (at least 240 $\mathrm{m})$ from any of the entrances, is located in the dark zone of the cave, is not straightforward to be reached, has no sediment accumulation and no apparent unique feature that may cause an animal to enter $\mathrm{CP}$ searching for water or nutrients. The material analysed has no predator marks and is minimally represented by animals that live in caves. Also, there is no evidence of water (or sediments) flow towards $\mathrm{CP}$, due to the lack of erosive marks, flow channels, stream sediments and associated fluvial features. Therefore, apparently once animals were inside the cave, they wandered through its passages and ended up falling in CP. As previously mentioned, the only access to this site is through a nearly vertical slope in smooth calcite flowstone that most probably does not allow the return of many species. In the entire cave, $\mathrm{CP}$ is the only passage that may provide a natural trap for a lost animal.

At present, CP contains one shallow pool but a well-defined horizontal calcite mark (Fig. 3) at approximately $1.9 \mathrm{~m}$ above the floor demonstrates that the passage was flooded at that level during a somewhat prolonged time period in the past. Although unfeasible to test at the present moment, the former presence of a deep pool inside CP during animal entrapment (which would not allow the animals to reach the bottom), could make the task of leaving the passage even more difficult.

Finally, the question remains on how all those animals (excluding bats), especially Cervidae, entered the cave. They could have entered by their own means (process (iii)), a mechanism named as "autopod" by Vrba (1980) in her study of fossil bovid remains, or again due to process (ii). Lapa Nova has only three possible entrance routes. The main entrance, nowadays used by tourists and pilgrims, does not allow straightforward access to $\mathrm{CP}$ due to a vertical $4 \mathrm{~m}$ high wall that would prevent deer (and other animals in general) penetration. Two other entrances are closer to CP. One of them (labelled A in Fig. 1) lies about $240 \mathrm{~m}$ from CP and contains a vertical drop $15 \mathrm{~m}$ high. It is unlikely, although possible, that a large animal such as a deer, would survive unhurt such fall. Østbye et al. (2006, p. 148) mentioned that one Gulo gulo (10-25 kg) survived a $40 \mathrm{~m}$ fall at a cave entrance, although fractured its hind limbs. Kos (2003, p. 773775) comments that eight animals from five species (all smaller than Mazama america or M. guazoubira which weigh between 11-48 kg; Trolle and Emmons, 2004) survived a $15 \mathrm{~m}$ fall in a cave and four (belonging to Rattus fucipes and Cercatetus nanus) had some bone breakage, although none in long bones. It appears that small animals tend to deal well with such falls, but the behaviour of a much larger animal such as deer that has relatively delicate long bones is difficult to infer. Some pattern of bone breakage is perhaps to be expected at entrance A, which contributes to making it an unlikely, although possible, entrance route for the majority of the animal remains found inside $\mathrm{CP}$.

Therefore, it is suggested here that most animals found in CP entered the cave by the autopod mechanism through another entrance (named B in Fig. 1), that lies $320 \mathrm{~m}$ from CP. Entrance B is a collapsed chamber with large boulders that may provide, although with some difficulties, a much more favourable entrance route. The autopod mechanism is supported by findings in other caves, such as Cuvieri Cave, which shows that a variety of taxa entered it by their own mean and got trapped (Hubbe et al., 2011). Once past the entrance B the passage slopes towards the dark zone. Since Lapa Nova is a maze cave, it is easy to get lost inside it as it presents several alternatives for any wandering animal, eventually leading to entrapment at $\mathrm{CP}$.

\section{Chronology of bone emplacement}

In order to bracket the time range of bone accumulation, a total of 5 AMS radiocarbon dates were obtained (Table 1). Location of samples is shown in Fig. 2. Sample LN-1 comes from a Mazama's right astragalus at the distal southernmost extension of CP. It yielded a conventional radiocarbon age of $5040 \pm 30$ yr BP (5610 - 5890 cal yr BP). Sample LN-2 represents a Cervidae's left astragalus from 
Table 1. Radiocarbon dates for bone samples from Cervid Passage, Lapa Nova.

\begin{tabular}{|l|l|l|l|l|l|}
\hline Sample & Lab number & Material dated & $\delta{ }^{13} \mathrm{C} \%$ & $\begin{array}{l}\text { Conventional age } \\
\left({ }^{14} \mathrm{C} \text { yr BP }\right)\end{array}$ & $\begin{array}{l}2 \sigma \text { Calibration } \\
(\text { Cal yr BP })\end{array}$ \\
\hline LN-1 & UGAMS 06128 & Collagen & -23.1 & $5,040 \pm 30$ & $5,610-5,890$ \\
\hline LN-2 & UGAMS 06129 & Collagen & -23.4 & $4,320 \pm 30$ & $4,650-4,960$ \\
\hline LN-3 & UGAMS 07510 & Collagen & -22.2 & $4,420 \pm 25$ & $4,850-5,040$ \\
\hline LN-4 & UGAMS 07511 & Collagen & -22.6 & $980 \pm 20$ & $790-920$ \\
\hline LN-5 & UGAMS 07512 & Collagen & -21.5 & $4,490 \pm 25$ & $4,880-5,280$ \\
\hline
\end{tabular}

the northernmost portion of $\mathrm{CP}$, close to the edge of the entrance drop and by the side of the shallow pool. This sample has provided a date of $4320 \pm 30$ yr BP (4650 - 4960 cal yr BP). LN-3 comprises an isolated Mazama's right astragalus lying close to the pool, slightly covered by fine grained sediment. It has yielded an age of $4420 \pm 25$ yr BP (4850 - 5040 cal yr BP). Sample LN-4 is a Cervidae's lumbar vertebrae from the low ceiling portion of the passage. It has a fresh appearance and displays a whitish colour, suggesting a younger age. Indeed, LN-4 yielded a date of $980 \pm 20 \mathrm{yr}$ BP $(790-920 \mathrm{cal}$ yr BP). The final sample, LN-5 comes from the final portion of the CP, close to its eastern wall. It comprises a Mazama's right astragalus of an individual with the remaining bones in close anatomical proximity. A radiocarbon age of $4490 \pm 25 \mathrm{yr} \mathrm{BP}(4480-5280$ cal yr BP) was obtained for this sample.

The dates available show that at least $\sim 5,000$ yrs were required for bone accumulation at $\mathrm{CP}$, the lack of further dates preventing a more precise bracketing of the process. Also, the overlap of samples LN-2, LN-3 and LN-5 within the calibrated ages, may suggest a more intense period of deer emplacement around 4900 yr BP. Furthermore, in cave environments, depending on the processes involved, there may be a considerable temporal gap between animal death and bone emplacement, especially in situations where runoff or underground streams bring bone material into the cave from outside sources (Simms, 1994). This is not the case at Lapa Nova, since it is believed that the emplacement process involved most probably the autopod mechanism followed by trapping. The dates at $\mathrm{CP}$, thus, probably represent the actual dates of in situ animal death and bone accumulation at the site.

\section{Integrating Evidences}

The absence of animal marks on the bones, distance from the cave entrances, bones sometimes in close anatomical proximity, general absence of post depositional alteration, and lack of evidence of water (or sediment) runoff strongly suggest that deer entered the cave either by falling or by their own means (autopod mechanism) and after that got trapped at $\mathrm{CP}$. As argued above, it is believed that the majority of animals entered the cave by the autopod mechanism. Indeed, Sutcliffe (1985) and Romero (2009) suggested that a great variety of non-cave adapted species will go underground of their own free will.

However, the reason for the major dominance of Cervidae at $\mathrm{CP}$ is unknown. It is unclear why deer appears to be more prone to enter caves or to get trapped in a passage such as CP. Some possibilities are: (i) Mazama (and other species such as tapir, wild pig, some monkeys, rodents and birds) shows the behaviour of licking the soil in search of nutrients (Montenegro, 2004; Tobler et al., 2009), suggesting that the search for cave saltpetre may be one reason why this animal may go into caves, as hypothesised by cave palaeontologist Peter Wilhelm Lund as early as 1845 in his study of fossils in Brazilian caves (Lund, 1845); (ii) Cervids (and wild pig, another very common mammal in cave deposits) are known to have well-developed sense of smell that could help them walk through the dark areas of the cave (Eisenberg \& Redford, 1999); (iii) water appears to be one reason that commonly attracts animals into caves, especially in dry areas. Although $\mathrm{CP}$ has at present a shallow pool (and may have contained a much larger one in the past), other areas of the cave also contains lakes that are easier to access. Santa Catarina river is an active stream a few kilometers from the cave, and thus there appears to be no reason for entering CP in search of water. Although these reasons may explain why Cervidae enter caves they do not account for the uniqueness of deer accumulation in $\mathrm{CP}$, since the characteristics that may favour their entrance are shared with other mammalian families.

The dominance of cervids in the Lapa Nova deposit, therefore, is an open question and may also reflect an abundance of this species in the region during the time span of the deposit, although this possibility cannot be properly assessed at present. However, Mazama is an extremely common genus in the fossil record of Brazilian caves (see Auler et al., 2006 for a review), and $\mathrm{CP}$ is the most remarkable case reported so far. However, other caves show a trend towards accumulation of cervid remains when compared to other taxa. At Toca do Serrote do Arthur, a limestone cave in Brazil's semi-arid northeastern state of Piauí, about 30 individuals were found in an early Holocene layer (Faure et al., 1999). The late Pleistocene/Holocene pitfall deposit within Cuvieri Cave (Hubbe et al., 2011), in the Lagoa Santa karst area, has also yielded a majority of Cervidae individuals (unpublished results) at least considering animals heavier than $5 \mathrm{~kg}$.

Although it is not possible at the present moment to elucidate the issue presented above, the reason for the accumulation of bones at CP is easier to conceive. Lapa Nova is a maze cave in which a number of intersections provide numerous routes for any given animal wandering in the dark. Regardless of the 
entrance route (i.e. autopod through entrance B or fall by entrance A), both would lead a deer to a confusing intersection of passages. It is possible to establish a probabilistic scenario that would result in a lost deer falling into CP. Fig. 1 shows the many passage crossings in the eastern portion of Lapa Nova. Of all possible routes, only two passage intersections (labelled "X" and "Y" in Fig. 1) would lead a wandering animal into a non-return situation. The crossing " $X$ " takes the animal into the twilight of the main entrance. Its $4 \mathrm{~m}$ vertical drop does not allow for the return to the eastern portion of the cave and the animal, if unhurt, would most probably leave the cave through the main entrance. The crossing "Y" takes the animal into $\mathrm{CP}$, a natural trap that makes a return impossible, due to the steepness and slippery nature of the calcite flowstone. Furthermore, if a deep lake existed in that passage (as suggested by calcite water level shelves at walls) at the time of animal emplacement, climbing back would be made even more difficult. All other passages would allow for the return of the animal that could either keep wandering and die in another area of the cave or eventually leave it through the main entrance or entrance B. Supposing that a lost animal goes through all passages of Lapa Nova, there would be a high possibility that it may get trapped into $\mathrm{CP}$ and become starved to death. Because CP is the only site in the entire cave that represents a dead end non-return passage, even if a wandering deer dies elsewhere in the cave, there would be no trend of bone accumulation.

Assuming a minimal time range of 5,000 yrs for cervid trapping, in average one individual at every 41 yr interval would be required to account for the minimum number of 121 cervids. This must be taken as an upper limit entrapment ratio, since the time span may be much greater. Moreover, the entrapment ratio could be non-linear because there may have been periods in which cervid emplacement was faster, as suggested by the clustering of three radiocarbon dates. Furthermore, the total number of cervids that entered the cave is probably much greater since, giving the number of possible underground routes, chances of a wandering deer getting trapped at $\mathrm{CP}$ are rather small, leaving the cave (or dying in any other passage) being probably the most common outcome of deer penetration. The lack of Pleistocene dates at Lapa Nova might suggest that the entrance routes (especially entrance B) were not accessible during the Pleistocene. M. Americana is probably restricted to forested areas while M. guazoubira is a generalist living in forest as well in open areas (Eisenberg \& Redford, 1999). An environmental change towards a more forested environment during mid-Holocene may have increased the number of Mazama in the surroundings of Lapa Nova, allowing for more frequent penetration at the cave at that time period.

Finally, Cartelle \& Bohorquez (1982) reported a similar case as the one presented here in which several Eremotherium (extinct ground sloth) specimens from different ontogenetic stages were found in a same level at the pitfall cave of Toca das Onças in semiarid northeastern Brazil. These authors interpreted their finding as a herd of animals entering the cave in search of water. However, the findings at CP show that these characteristics are not necessarily associated to a unique episode of entrapment. Although the ages of emplacement at $\mathrm{CP}$ are restricted to less than $5 \%$ of the recorded minimum number of cervids, they suggest that not all animals got trapped at the same time. Moreover, Mazama americana and M. guazoubira are solitary dwellers (Einsenberg \& Redford, 1999). Therefore, it is possible that the Toca das Onças deposit represents the entrapment of animals from different periods of time rather than a single event of herd entrapment and a refined excavation or better chronological assessment of the site will help clarifying this question.

\section{CONCLUSIONS}

Caves present a number of specific taphonomic controls that may bias bone accumulation in ways not frequently observed at the surface. Bones of over a hundred cervid individuals occur at a single site at Lapa Nova. Due to the lack of animal marks on the bones, general absence of post depositional alteration (besides human fragmentation) and no evidence of water (or sediment) flow towards $\mathrm{CP}$ it is interpreted that cervids, after entering the cave by their own means, got trapped at the only passage in the entire cave that would not allow for a return. The combination of major selective processes (and probably a few other minor ones) were at play: (i) the proneness of a cervid to enter caves or general abundance nearby Lapa Nova's entrances and (ii) the impossibility of a cervid leaving $\mathrm{CP}$.

Ages of bone emplacement were obtained through radiocarbon collagen dating, suggesting a midHolocene age for the deposit, with a time span of at least 5,000 yr. The clustering of three ages around 4,900 cal yr BP may suggest a higher abundance of deer at that time period. The lack of older dates may be related to a Holocene change in entrance morphology that favoured deer penetration into the cave. Cave environments are unique in allowing for a number of selective processes that favour both bone preservation and taphonomic selection, resulting in an accumulation that requires a careful approach in order to provide meaningful palaeoenvironmental and taphonomic information.

\section{ACKNOWLEDGEMENTS}

We would like to thank Walter Neves for his comments on a previous draft of this manuscript. Sampling at Lapa Nova was performed through SISBIO permit 22755-1. We acknowledge the help of local guide Severino. Gabriela Rosário helped with figures. We also thank FAPESP for a scholarship given to $\mathrm{AH}(08 / 58554-3)$.

\section{REFERENCES}

Auler A.S., Piló L.B., Smart P.L., Wang X.F., Hoffmann D., Richards D.A., Edwards R.L., Neves W.A. \& Cheng H., 2006 - U-series dating and taphonomy of Quaternary vertebrates from Brazilian caves. Palaeogeography, Palaeoclimatology, Palaeoecology, 240: 508-522.

http://dx.doi.org/10.1016/j.palaeo.2006.03.002 
Behrensmeyer A.K., Kidwell S.M. \& Gastaldo R.A., 2000 - Taphonomy and paleobiology. Paleobiology, 26: 103-147.

http://dx.doi.org/10.1666/0094-8373 (2000)26[103:TAP]2.0.CO;2

Bittencourt C., Auler A.S., Reis Neto J.M., Bessa V. \& Silva M.V.A., 2009 - The influence of hypogene and epigene speleogenesis in the evolution of the Vazante Karst, Minas Gerais state, Brazil. In: Klimchouk A.B. \& Ford D.C. (Eds) - Hypogene Speleogenesis and Karst Hydrogeology of Artesian Basins. Ukrainian Institute of Speleology and Karstology Special Paper, 1: 193-199.

Brain C.K., 1995 - Understanding the stratigraphic complexity of South African australopithecine cave deposits: the contribution of John T. Robinson. South African Journal of Science 91: 435-437.

Campy M. \& Chaline J., 1993 - Missing records and depositional breaks in French late Pleistocene cave sediments. Quaternary Research, 40: 318-331. http://dx.doi.org/10.1006/qres.1993.1085

Cartelle C. \& Bohorquez G.A., 1982 - Eremotherium laurillardi Lund, 1842. Parte I. Determinação especifica e dimorfismo sexual. Iheringia, 7: 45-63.

De Waele J., Brook G.A. \& Oertel A., 2009. Monk seal (Monachus monachus) bones in Bel Torrente cave (central east Sardinia) and their paleogeographical significance. Journal of Cave and Karst Studies, 71: 16-23.

Eisenberg J.F \& Redford K.H., 1999 - Mammals in the neotropics, the central neotropics, Ecuador, Peru, Bolivia, Brazil. The University of Chicago Press, Chicago, 624p.

Faure M., Guérin C \& Parenti F., 1999 - The Holocene megafauna from the Toca do Serrote do Artur (São Raimundo Nonato, Piaui, Brazil). Comptes Rendus Academie des Sciences de Paris, 329: 443-448.

Hubbe A., Haddad-Martim P.M., Hubbe M., Mayer E.L., Strauss A., Auler A.S., Piló L.B. \& Neves W.A., 2011 - Identification and importance of critical depositional gaps in pitfall cave environments: The fossiliferous deposit of Cuvieri Cave, eastern Brazil. Palaeogeography, Palaeoclimatology, Palaeoecology, 312: 66-78. http://dx.doi.org/10.1016/j.palaeo.2011.09.010

Jass C.N. \& George C.O., 2010 - An assessment of the contribution of fossil cave deposits to the Quaternary paleontological record. Quaternary International, 217: 105-116.

http://dx.doi.org/10.1016/j.quaint.2009.11.008

Kos A.M., 2003 - Pre-burial taphonomic characterization of a vertebrate assemblage from a pitfall cave deposit in southeastern Autralia. Journal of Archaeological Science, 30: 769-779.

http://dx.doi.org/10.1016/S0305-4403(02)00251-0

Kurtén B., 1995 - The cave bear story: Life and death of a vanished animal. Columbia University Press, New York, 163 p.

Lam Y.M., Chen X. \& Pearson O.M., 1999 - Intertaxonomic variability in patterns of bone density and the differential representation of bovid, cervid, and equid elements in the archaeological record. American Antiquity, 64: 343-362. http://dx.doi.org/10.2307/2694283
Lund P.W., 1845 - Notice sur des ossements humains fossiles, trouvés dans une caverne du Brésil. Mémoires de la Societé Royale des Antiquaires du Nord: 49-77.

Macken A.C., Jankowski N.R., Rice G.J., Bestland E.A., Reed E.H., Prideaux G.J. \& Roberts R.G., 2011 - Application of sedimentary and chronological analysis to refine the depositional context of a late Pleistocene vertebrate deposit, Naracoorte, South Australia. Quaternary Science Reviews, 30: 2690-2702.

http://dx.doi.org/10.1016/j.quascirev.2011.05.023

Montenegro O.L., 2004 - Natural licks as keystone resources for wildlife and people in Amazonia. $\mathrm{PhD}$ Thesis, University of Florida, $129 \mathrm{p}$.

Muldoon K.M., de Bilieux D.D., Simons E.L. \& Chatrath P.S., 2009 - The subfossil occurrence and paleoecological significance of small mammals at Ankilitelo cave, southwestern Madagascar. Journal of Mammalogy, 90: 1111-1131. http://dx.doi.org/10.1644/08-MAMM-A-242.1

Østbye E., Lauritzen S.E., Moe D. \& Østbye K., 2006 - Vertebrate remains in Holocene limestone cave sediments: faunal succession in the Sirijorda Cave, northern Norway. Boreas, 35: 142-158. http://dx.doi.org/10.1111/j.1502-3885.2006.tb01118.x

Paula Couto C. 1971 - Mamíferos fósseis das cavernas de Minas Gerais. Espeleologia, 3: 3-14.

Piló L.B., Auler A.S., Neves W.A., Wang X.F., Cheng H. \& Edwards R.L., 2005 - Geochronology, sediment provenance, and fossil emplacement at Sumidouro Cave, a classic late Pleistocene/early Holocene paleoanthropological site in eastern Brazil. Geoarchaeology, 20: 751-764.

http://dx.doi.org/10.1002/gea.20081

Romero A., 2009 - Cave Biology. Life in Darkness. Cambridge University Press, New York, 291 p. http://dx.doi.org/10.1017/CBO9780511596841

Simms M.J., 1994 - Emplacement and preservation of vertebrates in caves and fissures. Zoological Journal of the Linnean Society, 112: 261-283.

http://dx.doi.org/10.1111/j.1096-3642.1994.tb00320.x

Stuiver M \& Reimer P.J., 1993 - Extended 14C data base and revised CALIB 3.0 14C age calibration program. Radiocarbon, 35: 215-230.

Sutcliffe A.J., 1985 - On the Track of Ice Age Mammals. Harvard University Press, Cambridge, 224 p.

Tobler M.W., Carrillo-Percastegui S.E. \& Powell G., 2009 - Habitat use, activity patterns and use of mineral licks by five species of ungulate in southeastern Peru. Journal of Tropical Ecology, 25: 161-270.

http:/ /dx.doi.org/10.1017/S0266467409005896

Trolle M. \& Emmons L.H., 2004 - A record of a dwarf brocket from lowland Madre de Dios, Peru. Deer Specialist Group Newsletter, 19: 2-5.

van den Bergh G.D., Meijer H.J.M., Awe R.D., Morwood M.J., Szabo K., Ostende L.W.V., Sutikna T. \& Saptorno E.W., 2009 - The Liang Bua faunal remains: a 95 k.yr. sequence from Flores, East Indonesia. Journal of Human Evolution, 57: 527-537. http://dx.doi.org/10.1016/j.jhevol.2008.08.015 
Vrba E.S., 1980. The significance of bovid remains as indicators of environment and predation patterns. In: Behrensmeyer A.K. \& Hill A.P. (Eds). - Fossils in the Making. University of Chicago Press: 247-271.

Ward B.C., Wilson M.C., Nagorsen D.W., Nelson D.E., Driver J.C. \& Wigen R.J., 2003 - Port Eliza cave: North American West Coast interstadial environment and implications for human migrations. Quaternary Science Reviews, 22: 1363-1388.

http://dx.doi.org/10.1016/S0277-3791(03)00092-1
White J.A., McDonald G.H., Anderson E. \& Soiset J.M., 1984 - Lava blisters as carnivoran traps. Special Publication Carnegie Museum of Natural History, 8: 241-255. 